\title{
Analysis of the genus Allium L. Tersky Caucasus and Dagestan
}

\author{
Aishat Umaeva*, Zlata Shakhgirieva, and Yakha Sirieva \\ Kadyrov Chechen State University, 31, L. Yashina, st., Chechen Republic, Grozny, \\ Russian Federation
}

\begin{abstract}
The article provides data on the species of the genus Allium L., known for many useful plants - food, medicinal, ornamental, as well as rare species in need of protection. The collection includes 36 species. The richest set of diverse vegetation species demonstrates evolutionary and ecological adaptation to different environments. Natural resources fulfill an ecological function that supports a social and economic system for humans. The ability of the biosphere to heal itself forms that ecological capacity. The ability of the biosphere to self-repair forms that ecological capacity. The current stage of development of research on the genus Allium poses qualitatively new problems for us. The solution of the latter requires extensive comparisons and generalizations of data, knowledge not only of the diversity of plant communities and the patterns of their development, but also of the systematic diversity and ecological and biological characteristics of the species composing them.
\end{abstract}

\section{Introduction}

Onion species of the genus Allium in mountainous regions are distinguished by an increased rate of evolution and a higher rate of formation of new species forms in comparison with the plains [1-4]. Mountain ecosystems are the centers of origin of many varieties of food, decorative, medicinal of this genus, widely cultivated by humans. The Romans believed that the strength and courage of a soldier increases with the use of onions, so it was included in the military diet. According to various authors, it includes from 500 to 750 species. On the territory of Russia and neighboring states, there are 332 types of onions. Cultivated species of onions are common in all parts of the world. At the same time, their varieties have become isolated within the species. Onion is the most widespread in culture [5].

In Egypt, the bow was honored as a deity. Under Hippocrates, onions were prescribed for patients with rheumatism, gout, and obesity. The famous Persian physician and scientist Ibn Sina (Avicenna) at the beginning of the 11-th century wrote about onions: "Edible onions especially help from the harm of bad water, if you throw onion peels into it, this is one of the means that destroy its smell. Onion juice is useful for contaminated wounds,

\footnotetext{
"Corresponding author: 0892179@mail.ru
} 
lubricating the eyes with squeezed onion juice with honey is useful for thorns. Onion juice helps with sore throat. The bitterness of the edible onion strengthens a weak stomach and stimulates the appetite. In the East, there was a saying: "Onions in your arms - every disease passes." The time of the appearance of onions in Russia has not been precisely established, but it is known that for a long time it was one of the main food products and was considered a universal remedy that preserves and cures diseases. In the old Russian herbal medicine the following recommendation was given: "during the pestilencefesses or other sticky diseases need to be hung in the rooms with bundles of bulbs, which is why the infection does not penetrate into them, and the air in the rooms will be cleansed so as not to get infected. " Professor N. Z. Umikov cites the testimony of his contemporaries that during the great epidemic of typhoid fever in 1805 , the Russians, who consumed large quantities of onions, did not fall ill with typhus and plague.

Onions are a good vitamin remedy, especially recommended in the winter-spring period, but used all year round. A significant amount of mineral salts in onions, when used in food, contributes to the normalization of water-salt metabolism in the body, and a peculiar smell and pungent taste stimulate the appetite.

It has been shown that Allium species may help to prevent tumor promotion, cardiovascular diseases and aging; all processes that are associated with free radicals [6-8].

To date, more than 40 glycosides of furostanol and spirostanol nature have been isolated from plants of the genus Allium; their carbohydrate chains include D-glucose, D-xylose, Dgalactose, L-rhamnose, and L-arabinose. Of the 26 genins discovered by the end of the last century, the most common is diosgenin, found in 18 types of onions. Onion leaves contain a lot of vitamin C (15-20 times more than in lemons), essential oil, protein, soluble mineral and nitrogen-free extractives, alanine glycoside and natural antibiotic lysozyme, phytoncides.

Many types of onions can contain:

a) carbohydrates, essential oil - $0.007 \%$, prostaglandins, sulfur-containing compounds alliin, allyl isothiocyanate, ascorbic acid - vitamin C - $750 \mathrm{mg} \%$ (in bulbs $50-100 \mathrm{mg} \%$, in fresh leaves up to $7 \mathrm{mg} \%$ ), flavonoids, saponins, aliphatic aldehydes, phenol carboxylic acids, lysozyme, phytoncides, mucus, sugar - $0.3 \%$ citric acid - $0.05 \%$, trace elements: iron, manganese, zinc, copper, chromium, molybdenum, etc. In addition, wild garlic leaves contain a natural antibiotic lysozyme.

b) sugars, protein, calcium, phosphorus, iron, carotene, vitamins $\mathrm{B}_{1}$; $\mathrm{B}_{2}$, PP and C. $100 \mathrm{~g}$ of chives contains $75 \mathrm{mg}$ of ascorbic acid. It contains similar essential oils, as in onions, which give the chives onion similar taste and medicinal properties and determine its value.

c) nitrogenous substances (up to 2.5\%), various sugars (10-11\%) (glucose, fructose, sucrose, maltose), the polysaccharide inulin, phytin, the flavonoid quercetin and its glucosides, fats, various enzymes, calcium and phosphorus salts, phytoncides, citric and malic acids, vitamins A (3.75 mg\%), B $160 \mathrm{mg} \%), \mathrm{B}_{2}(50 \mathrm{mg} \%)$, PP (0.20 mg\%), C (10.5$33 \mathrm{mg} \%)$ ), as well as an essential oil with a pungent special odor that irritates the mucous membranes of the eyes and nose. The main constituent of the essential oil is disulfide and other sulfides, the main part of which is the disulfide $\mathrm{C}_{6} \mathrm{H}_{12} \mathrm{~S}_{2}$, which contains a lot of sulfur. All parts of the plant contain sulfur-containing hydrocarbons such as allicin, essential oil of unstudied composition and ascorbic acid: in the leaves - up to $0.73 \mathrm{mg} / \%$, in the bulbs - 50-100 $\mathrm{mg} / \%$.

\section{Methods}

The object of the study is the genus Allium of the Tersk Caucasus. When performing the analysis of this work, the herbarium materials collected during the expeditionary research of the Department of Botany of the Chechen State University (now the Chechen State 
University named after A.A. Kadyrov) in 1998-2020 were used,within the framework of economic contractual topics. Field research diaries were kept during the expeditions. In the diaries, in addition to floristic and geobotanical information, observations of a phenological and ecological nature were recorded. During this period, we collected extensive material, which was included in the herbarium fund of the botany department of the named university. The work was carried out both in field research and in the subsequent office processing of the collected material.

The field study of the genus Allium was carried out by route-expedition methods. For the collection and herbarization of plants, they used the traditional equipment required for floristic research. When identifying plants in laboratory conditions, we used an MBS-2 binocular microscope, and in the field, we used magnifiers with 8x magnification.

The Greater Caucasus forms a grandiose meganticlinorium with a folded-block structure and a general Caucasian strike. In the most elevated central part of the axial zone, the meganticlinorium is composed of rocks of the Hercynian basement concentrically surrounded on the wings and in the eastern part by transgressive sediments of the Jurassic complex. Further to the north and south, the zones of Cretaceous, Paleogene, Miocene and Pliocene deposits are successively replaced. The Hercynian and Mesozoic complexes are crumpled into fan-shaped, partly overturned, and isoclinal folds, broken by faults and thrusts, especially along the steep and short southern slope.

The Eastern Caucasus differs markedly from the Central one. The Paleozoic basement is not exposed anywhere here; Lower Jurassic rocks reach enormous thickness and compose the entire axial zone of the folded structure, forming two private horst-anticlinoria - the Lateral ridge and the Vodorazdelny ridge, separated by a narrow graben-synclinal Bezhitinsky depression. The first is a continuation of the southernmost block of the Anticlinorium of the Dividing Range of the Central Caucasus, the second, possibly, is a continuation of the Svanetian anticlinorium. Strongly compressed straight folds are observed in the cores of both anticlinoria. To the north of the axial strip stretches a rather wide zone of Limestone Dagestan with relatively calm folding of the Middle Jurassic terrigenous strata and carbonate deposits of the Upper Jurassic and Cretaceous.

It is characterized by box-shaped anticlines and synclines. These structures are elongated arcuate and coincide with the "lateral" ridges of Dagestan - Gimrinsky, Salatau and some others, as well as with extensive synclinal plateaus - Levashinsky, Akushinsky, Gunibsky, etc. Limestone Dagestan is separated by a longitudinal flexure from the TerekCaspian foredeep. The Chiauro-Dibrar synclinorium stretches along the southern wing of the Eastern Caucasus, filled with Upper Jurassic-Lower Paleogene flysch, crumpled into a complex series of isoclinal folds, disturbed by scaly thrust faults. Throughout this zone, the movement of the masses to the south prevailed, and in some places (in the mountainous Kakheti) even small tectonic covers were formed.

\section{Results}

The object of the study is the genus Allium of the Terek Caucasus. Herbarium materials collected during the expeditionary research of the Department of Botany of the Chechen State University (now the Kadyrov Chechen State University) in 1998-2020 within the framework of contractual topics were used in the analysis of this work. Field research diaries were kept during the expeditions. In addition to floristic and geobotanical information, observations of a phenological and ecological nature were recorded in the diaries. During this period, we collected extensive material, which was included in the herbarium fund of the Department of Botany of the named university. The work was carried out both in field research and in the subsequent in-house processing of the collected material. The field study of the genus Allium was carried out by route-expedition methods. 
For the collection and herbarization of plants, traditional equipment necessary for floral research was used. When determining plants in the laboratory, MBS-2 binoculars were used, and in the field, magnifying glasses with 8-fold magnification were used.

The Greater Caucasus forms a grandiose meganticlinorium with a folded-block structure and a general Caucasian strike. In the most elevated central part of the axial zone, the meganticlinorium is composed of rocks of the Hercynian basement concentrically surrounded on the wings and in the eastern part by transgressive sediments of the Jurassic complex. Further to the north and south, the zones of Cretaceous, Paleogene, Miocene and Pliocene deposits are successively replaced. The Hercynian and Mesozoic complexes are crumpled into fan-shaped, partly overturned, and isoclinal folds, broken by faults and thrusts, especially along the steep and short southern slope. The Eastern Caucasus differs markedly from the Central one. The Paleozoic basement is not exposed anywhere here; Lower Jurassic rocks reach enormous thickness and compose the entire axial zone of the folded structure, forming two private horst-anticlinoria - the Lateral ridge and the Vodorazdelny ridge, separated by a narrow graben-synclinal Bezhitinsky depression.

The first is a continuation of the southernmost block of the Anticlinorium of the Dividing Range of the Central Caucasus, the second, possibly, is a continuation of the Svanetian anticlinorium. Strongly compressed straight folds are observed in the cores of both anticlinoria. To the north of the axial strip stretches a rather wide zone of Limestone Dagestan with relatively calm folding of the Middle Jurassic terrigenous strata and carbonate deposits of the Upper Jurassic and Cretaceous. It is characterized by box-shaped anticlines and synclines. These structures are elongated arcuate and coincide with the "lateral" ridges of Dagestan - Gimrinsky, Salatau and some others, as well as with extensive synclinal plateaus - Levashinsky, Akushinsky, Gunibsky, etc. Limestone Dagestan is separated by a longitudinal flexure from the Terek-Caspian foredeep. The Chiauro-Dibrar synclinorium stretches along the southern wing of the Eastern Caucasus, filled with Upper Jurassic-Lower Paleogene flysch, crumpled into a complex series of isoclinal folds, disturbed by scaly thrust faults. Throughout this zone, the movement of the masses to the south prevailed, and in places (in mountainous Kakheti) even small tectonic covers were formed. The expedition research allowed us to make many interesting observations. A systematic analysis of the genus Allium of the Terek Caucasus and Dagestan was carried out and the geographical distribution of Allium species of the studied territory was investigated. The data are listed in table 1,2.

Table 1. Systematic composition of the genus Allium of the Tersk Caucasus.

\begin{tabular}{|c|c|c|}
\hline Subgenus & Section & View \\
\hline \multirow{13}{*}{ I. Rhizirideum } & 1. Anguinum & A. victorialis \\
\hline & 2. Rhizirideum & A. albidum \\
\hline & 3. Schoenoprasum & A. schoenoprasum \\
\hline & \multirow{8}{*}{ 4. Oreiprason } & A. saxatile \\
\hline & & A. globosum \\
\hline & & A. gunibicum \\
\hline & & Amirzajevii \\
\hline & & A. charadzeae \\
\hline & & A. salthynicum \\
\hline & & A. daghestanicum \\
\hline & & A. samurense \\
\hline & \multirow{2}{*}{ 5. Reticulato-bulbosa } & A. pseudostrictum \\
\hline & & A. szovitsii \\
\hline \multirow{3}{*}{ II. Allium } & \multirow{3}{*}{ 6. Allium } & A. rotundum \\
\hline & & A. erubescens \\
\hline & & A. leucanthum \\
\hline
\end{tabular}




\begin{tabular}{|c|c|c|}
\hline & & A. atroviolaceum \\
\hline & & A. fuscoviolaceum \\
\hline & & A. sphaerocephalon \\
\hline & & A. affine \\
\hline & & A. aucheri \\
\hline & & A. moschatum \\
\hline & 7. Scorodon & A. inaequale \\
\hline & & A. rubellum \\
\hline & & A. paczoskianum \\
\hline & & A. kunthianum \\
\hline & 8. Codonoprasum & A. rupestre \\
\hline & & A. paniculatum \\
\hline & & A. oleraceum \\
\hline & 9. Molium & A. candolleanum \\
\hline III. Amerallium & 10. Briseis & A. paradoxum \\
\hline & 11. Ophioscordon & A. ursinum \\
\hline & 12. Porphyroprason & A. oreophilum \\
\hline IVI $\mathrm{T}$ - & 13. Kaloprasum & A. caspium \\
\hline IV. Melanocrommyum & & A. decipiens \\
\hline & 14. Melanocrommyum & \begin{tabular}{|l|} 
A. grande \\
A
\end{tabular} \\
\hline
\end{tabular}

When distinguishing Allium subgenera, taxonomic significance is mainly attached to the following features: the structure of bulbs, leaf budding, nectaries, the location of conducting bundles and milkweeds, as well as chromosome numbers [9]. The subgenus Rhizirideum unites bulbous-rhizomatous, rarely rhizomatous representatives of the genus Allium. Its species mainly inhabit the northern hemisphere of the Old World, only a few representatives of this group are found in North America [10].

Rhizirideum is the most numerous subgenus of the genus Allium, with about 150 species. Six sections belong to this subgenus: Anguinum G. Don F. ex Koch, Rhizirideum, Schoenoprasum Koch, Oreiprason F. Herm., Phyllodolon Prokh., Sulfur (mill.) Prokh. The Anguinum section was installed by Koch in 1837. It was recognized only 100 years later by A.I. Vvedensky. The type species - A. victorialis L. has a large distribution area, the latter was included in the section Rhiziridium Don by Grossheim. The section is not numerous (about 10 species), it is distributed mainly in Eurasia, only 1 species is found in North America. We believe that this section, due to its characteristic, original features, is well worth highlighting.

The Rhizirideum section according to the author unites species with iris-like rhizomes and the group A. senescens L. is typical for it [11]. However, most researchers, following G. Don, include almost all bulbous-rhizomatous species in it. This section is widely interpreted by A.A. Grossheim. Unlike A.A. Grossheim, in the Caucasus, refers only one species to the Rhizirideum section A. albidum Fisch. ex Bieb. p. emend Bess. This section has about 20 species. Its range covers Central Europe, the Caucasus, Eastern and Central Asia. The Schoenoprasum section according to Koch includes species with piped leaves: A. schoenoprasum L., A. sulfur L., A. fistulosum L.

The Acanthoprason section was installed relatively recently. According to Wendelbo, this group unites species with rather short and thick flower arrows, as well as with characteristic, after flowering, spiny tepals. In the interpretation of Vendelbo, the section is also recognized by Ekberg. The representatives of the Acanthoprason section before its isolation were considered by researchers mainly within the sections Molium G. Don f. ex Koch or Melanocrommyum Webb et Berth. For the Acanthoprason Section, R.V. Kamelin gives a new interpretation, subordinating it to the Melanocrommyum section. N.B. Cholokashvili refers 3 subsections to the section Acanthoprason: Acanthacea Tscholok., Cristophiana Tscholok. and Schubertia Tscholok. As Wendelbo points out, this section is 
relatively well represented in the mountains of Kurdistan, Zagross, Elbursa and Kopetdag, as well as in Transcaucasia, its occurrence is much weaker in Afghanistan and Central Asia. Regarding the subsection Schubertia Tscholok. It can be added that according to R.V. Kamelin, it is characteristic of all Iranian-Turanian deserts, reaching the low mountains of Central Asia.

The Kaloprasum section, established in the middle of the 19-th century, according to the type species A. caspium Bieb. it was considered monotypic. It was recognized only after more than a hundred years by Wendelbo and Ekberg. Recognizing the independence of this section, Vendelbo interprets its scope in a different way. For example, based on the similar shape of the flower arrow and similar ecology, despite the sharp differences in the nature of the perianth and the length of the filaments of the stamens, the author includes the group A. schubertii Zucc. R.V. in it. Kamelin, considering this section in a new rank and in a new combination - sect. Melanocrommyum, subsect. Kaloprasum R.Kam. also changes its framework. In particular, the subsection is limited only to species close to the species A. caspium Bieb., and the group A. schubertii Zucc. rightly allocates to a special subsection Schubertia R. Kam. Of the four species of the Acanthoprason section peculiar to the eastern part of the deserts of Iran-Turan, as well as the low mountains of Central Asia, one species is found in the Caucasus: A. caspium (Pall.) Bieb.

The type section of Melanocrommyum was described by Webb and Bertle in the middle of the 19th century, while studying the bows of the Canary Islands. Webb and Bertle assigned only one species, A. nigrum L., to this section. This section was first recognized by Boissier, who included 15 species in it.

In 1939, Herman gave the section a new name - Melamprason and attributed 2 species to it. Soon Stern considered Herman's name superfluous [12-14]. At the same time, Stern interprets the volume of the Melanocrommyum section quite broadly.

It is interesting to note that Stern was the first to indicate this section for the flora of the USSR, in which he included almost all the species attributed by Vvedensky to the Molium Don Wendelbo divides the Melanocrommyum section into six sections that are not recognized by all researchers [15-17].

Kamelin understands the Melanocrommyum section much more broadly, including all six sections of Vendelbo. Section Melanocrommyum has about 70 species, most of them are peculiar to the mountains of Central Asia. There are only five of its representatives in the Caucasus.

Table 2. Geographic distribution of Allium species in the Terek Caucasus.

\begin{tabular}{|c|c|c|c|c|c|c|c|c|c|c|}
\hline № & Name of the species & 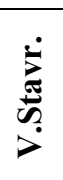 & 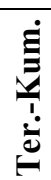 & 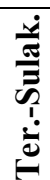 & 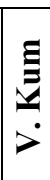 & $\frac{\dot{z}}{\underline{J}}$ & 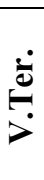 & 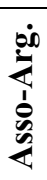 & 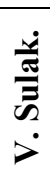 & 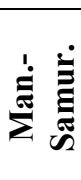 \\
\hline 1 & A. victorialis & - & - & - & + & + & + & + & + & + \\
\hline 2 & A. albidum & + & - & - & + & + & + & + & + & + \\
\hline 3 & A. schoenoprasum & - & - & - & + & + & + & + & - & - \\
\hline 4 & A. saxatile & - & - & - & + & + & + & + & + & + \\
\hline 5 & A. globosum & - & - & - & + & + & + & - & - & + \\
\hline 6 & A. gunibicum & - & - & - & - & - & - & - & + & - \\
\hline 7 & A. mirzajevii & - & - & - & - & - & - & - & + & - \\
\hline 8 & A. charadzeae & - & - & - & - & - & - & - & - & + \\
\hline 9 & A. salthynicum & - & - & - & - & - & - & - & + & - \\
\hline 10 & A. daghestanicum & - & - & - & - & - & - & - & + & - \\
\hline 11 & A. samurense & - & - & - & - & - & - & - & - & + \\
\hline 12 & A. pseudostrictum & - & - & - & + & + & + & + & + & - \\
\hline 13 & A. szovitsii & - & - & - & - & - & - & - & - & + \\
\hline
\end{tabular}




\begin{tabular}{|c|c|c|c|c|c|c|c|c|c|c|}
\hline № & Name of the species & $\dot{\vec{\Delta}}$ & 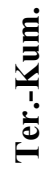 & 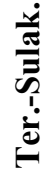 & $\begin{array}{l}\Xi \\
\Xi \\
z \\
\dot{z}\end{array}$ & $\frac{\dot{z}}{\bar{J}}$ & $\stackrel{\dot{\Xi}}{\stackrel{\dot{\nu}}{\ominus}}$ & 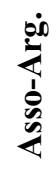 & 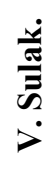 & 这 \\
\hline 14 & A. rotundum & + & + & + & + & + & + & + & + & + \\
\hline 15 & A. erubescens & - & - & - & + & + & + & + & + & + \\
\hline 16 & A. leucanthum & + & + & + & - & + & + & + & + & + \\
\hline 17 & A. atroviolaceum & + & + & + & + & + & + & + & + & + \\
\hline 18 & A. fuscoviolaceum & - & - & - & + & + & + & + & + & + \\
\hline 19 & A. sphaerocephalon & + & - & + & + & + & + & + & + & + \\
\hline 20 & A. affine & - & - & - & - & - & - & - & - & + \\
\hline 21 & A. aucheri & - & - & - & - & - & - & - & + & - \\
\hline 22 & A. moschatum & - & - & - & + & - & + & + & + & + \\
\hline 23 & A. inaequale & + & + & - & + & - & - & + & + & + \\
\hline 24 & A. rubellum & - & - & - & + & - & + & + & + & + \\
\hline 25 & A. paczoskianum & + & + & + & + & + & + & + & + & + \\
\hline 26 & A. kunthianum & - & - & - & + & + & + & + & + & + \\
\hline 27 & A. rupestre & + & - & - & - & - & - & - & - & - \\
\hline 28 & A. paniculatum & + & - & - & + & + & + & + & + & + \\
\hline 29 & A. oleraceum & - & - & - & - & - & - & - & - & + \\
\hline 30 & A. candolleanum & - & - & - & - & - & + & - & - & - \\
\hline 31 & A. paradoxum & - & - & - & - & - & - & + & + & + \\
\hline 32 & A. ursinum & - & - & - & + & + & + & + & + & + \\
\hline 33 & A. oreophilum & - & - & - & - & - & + & - & - & + \\
\hline 34 & A. caspium & - & + & + & - & - & - & - & - & - \\
\hline 35 & A. decipiense & + & - & - & + & - & - & - & - & - \\
\hline 36 & A. grande & - & - & - & - & - & - & - & - & + \\
\hline & Всего: & 10 & 6 & 6 & 19 & 16 & 20 & 19 & 23 & 25 \\
\hline
\end{tabular}

Comparison of the species diversity of Allium by flora regions using the SorensenChekanovsky similarity coefficient (Ksc) is indicative.

$$
K_{s c}=\frac{2 c}{a+b}
$$

where $a$ is the number of species in one area; $b$ is the number of species in another area; $\mathrm{c}$ - the number of species common to the two regions. The limits of the Ksc coefficient are from 0 to 1 . Ksc $=1$ means complete similarity, i.e. absolute coincidence of the lists, and $\mathrm{Ksc}=0$ means that the districts have no common form.

As can be seen from table 3. the highest value of this indicator has the similarity between V. Kum. and Asso-Arg. regions $(\mathrm{Ksc}=0.8947)$. In general, higher values for this coefficient are typical for the mountainous regions of the Terek Caucasus and Dagestan. If we pay attention to the similarity between the plain and mountainous regions, we find an emphasized low value of Ksc. Perhaps the closest species composition between the plains and mountainous regions is distinguished by V. Kum. and Asso-Arg. with V.Stavr. (Ksc = $0.5517)$.

Table 3. Coefficients of similarity of species composition of Sorensen-Chekanovsky (Ksc) (by regions of flora).

\begin{tabular}{|l|l|l|l|l|l|l|l|c|c|}
\hline & V.Stavr. & $\begin{array}{r}\text { Ter.- } \\
\text { Kum. }\end{array}$ & $\begin{array}{r}\text { Ter.- } \\
\text { Sulak. }\end{array}$ & V.Kum. & Malk. & V.Ter. & $\begin{array}{c}\text { Asso- } \\
\text { Arg. }\end{array}$ & $\begin{array}{c}\text { V. } \\
\text { Sulak. }\end{array}$ & $\begin{array}{c}\text { Man- } \\
\text { Samur. }\end{array}$ \\
\hline V.Stavr. & $\mathbf{1 0}$ & 5 & 5 & 8 & 7 & 7 & 8 & 8 & 8 \\
\hline
\end{tabular}




\begin{tabular}{|l|l|l|l|l|l|l|l|l|l|}
\hline Ter.-Kum. & 0,6250 & $\mathbf{6}$ & 5 & 4 & 4 & 4 & 5 & 5 & 5 \\
\hline Ter.-Sulak. & 0,6250 & 0,8333 & $\mathbf{6}$ & 4 & 5 & 5 & 5 & 5 & 5 \\
\hline V.Kum. & 0,5517 & 0,3200 & 0,3200 & $\mathbf{1 9}$ & 15 & 17 & 17 & 16 & 16 \\
\hline Malk. & 0,5385 & 0,3636 & 0,4545 & 0,8571 & $\mathbf{1 6}$ & 16 & 15 & 14 & 14 \\
\hline V.Ter. & 0,4667 & 0,3077 & 0,3846 & 0,8718 & 0,8889 & $\mathbf{2 0}$ & 17 & 16 & 17 \\
\hline Asso-Arg. & 0,5517 & 0,4000 & 0,4000 & 0,8947 & 0,8571 & 0,8718 & $\mathbf{1 9}$ & 18 & 17 \\
\hline V. Sulak. & 0,4848 & 0,3448 & 0,3448 & 0,7619 & 0,7179 & 0,7442 & 0,8571 & $\mathbf{2 3}$ & 17 \\
\hline Man-Samur. & 0,4571 & 0,3226 & 0,3226 & 0,7273 & 0,6829 & 0,7556 & 0,7727 & 0,7083 & $\mathbf{2 5}$ \\
\hline
\end{tabular}

Analysis of this table shows that the Sorensen-Chekanovsky coefficient, which illustrates the similarity of separate mountainous and lowland regions, exceeds the value of Ksc $=0.5$. This fact indicates that we can recognize the similarity of the species composition of mountainous and lowland regions within ourselves by more than half.

\section{Discussion}

Any system is based on taxonomic features, the degree of materiality and constancy of which depends on the natural division. The identification and assessment of these characters play an important role for a correct understanding of the essence of taxa. The accumulated data of recent years on morphology, biology, anatomy and karyology contribute to a better assessment of taxa of the genus Allium L. Considering the distribution of the genus Allium in the region of the Terek Caucasus and Dagestan, it can be noted that, with the breadth of distribution, onions still have a limited growing space. The size and shape of the geography of the various species of Allium are determined primarily by the conditions of their existence. They depend, on the one hand, on the ecological properties of the species: its requirements for temperature, air humidity, as well as on the physical and chemical properties of the soil. Summarizing the above, we note that in the formation of the modern species composition of Allium in the Terek Caucasus and Dagestan, on the one hand, migration flows from the Mediterranean were of decisive importance, and on the other, autochthonous speciation processes, especially at the level of the Oreiprason section. Thus, the genus Allium of the territory under consideration is Caucasian-Mediterranean in its botanical and geographical basis.

\section{Conclusion}

The extinction of biological species, including Allium species, is a natural process that takes place over a fairly long period of time. According to the estimates of different authors, the lifetime of a plant species is determined in the range from 1 million to 250 thousand years. The signs of the extinction of the species are the global disjunction of the range and the difficulty of seed renewal, the transition to vegetative reproduction. The process of natural extinction of species is largely accelerated by anthropogenic impact, and not only the extinct species, which are most sensitive to the intensification of anthropogenic pressure, are disappearing, but also the ecologically more plastic species, which are at the evolutionary peak of their development. The main reason for the disappearance of species is the disturbance of their habitat - plowing of steppe and meadows, deforestation, quarrying, road construction, etc. In second place in terms of the degree of impact is excessive grazing: in those places where the terrain has a steep slope and is unsuitable for agriculture, domestic animals, especially goats, cause great damage to populations of rare plant species. Species also disappear with the direct destruction of individual specimens. Particularly affected are those species that use the underground part, which are bows. The collection of rare species for bouquets leads to significant damage to the gene pool. 
In the flora of the Terek Caucasus and Dagestan, 36 species of Allium were found, belonging to 14 sections and 4 subgenera, which is approximately $5-7 \%$ of the total diversity of the genus and $10-11 \%$ of the species known within the administrative boundaries of the Russian Federation and the CIS countries. The largest number of species is represented by the subgenera Allium and Rhizirideum (respectively, about 16\% and 9\% of their planetary species diversity). Of the total species diversity, 3 species (A. leucanthum, A. kunthianum, A. szovitsii) are all-Caucasian, 1 species (A. candolleanum) is Eucaucasian, 1 species (A. grande) is East Caucasian, and 6 species (A. gunibicum, A. mirzajevii, A. charadzeae, A. salthynicum, A. daghestanicum, A. samurense) Dagestan endemics, which in total amounts to $30.56 \%$ of the total species diversity. Endemic species are characteristic only for the mountainous part of the study area. Of the altitudinal belts within the boundaries of the Terek Caucasus and Dagestan, the richest in terms of the number of species are the steppe, forest-steppe, semiarid belts, in which 15 species are recorded, which is $41.67 \%$ of the total number of species. The next in terms of species richness is the subalpine belt ( 13 species, or $36.11 \%$ ). The rest of the belts are much poorer in the Allium species than the forest belt. Alpine and semi-desert belts show very little similarity with other belts in terms of common species composition.

\section{References}

1. A.I. Vvedensky, Publishing house of the Academy of Sciences of the USSR, 4 (1935)

2. A.I. Galushko, Flora of the North Caucasus, 1 (1978)

3. G.L. Kudryashova, Bot. zhurn., 77, 4 (1992)

4. G.L. Kudryashova, Bot. zhurn., 86, 4 (2001)

5. T.Shirshova, G.Volkova, Amazing properties of an ordinary onion (2005)

6. R.N Singh, P. Kumar, D.K Singh, International journal of pharmaceutical sciences and research, 11 (2020)

7. E. Block, Garlic and other alliums: the lore and the science (2010)

8. M.M Ozcan, Bioactive properties of garlic, 21 (2016)

9. F.Hermann, Feddes Report. (1939)

10. C.A. Meyer, Verzeichniss der Pflanzen welche wahrend der auf. (SPb, 1831)

11. K. Koch, Beitrage zu einer Flora des Orientes (1851)

12. W. G. Stearn, Herbertia, 11 (1944)

13. W.Stearn, Bull. Brit. Mus. (Nat. Hist.) (1960)

14. W. G. Stearn, Ann. Mus. Goulandris, 4, (1978)

15. P. Wendelbo, Nytt. Mag. Bot., 14 (1967)

16. P. Wendelbo, Bot. Notiser., 122 (1969)

17. P.Wendelbo, Flora Iranica (Graz-Austria, 1971) 